\title{
APLIKASI FUZZY INFERENCE SYSTEM UNTUK MENENTUKAN LOKASI PENGEMBANGAN SENTRA PETERNAKAN RAKYAT (SPR) SAPI POTONG DI KABUPATEN JEMBER
}

\author{
Bambang Herry Purnomo*, Yuli Wibowo \\ Staf Pengajar Teknologi Industri Pertanian, FTP, Universitas Trunojoyo \\ Penulis korespondensi: binauf06@yahoo.com
}

\begin{abstract}
The development of community farming center (SPR) of cattle beef to consolidate the potential of people's cattle beef to be managed optimally to increase the production and welfare of farmers in realizing national beef self-sufficiency. Jember Regency as one of the centers of cattle beef in East Java Province has a policy to develop SPR in a number of sub-districts but still faces a number of problems that is determining which district will be chosen as SPR location. This research aims to design the model of determining SPR cattle beef location using fuzzy inference system technique. A number of key criteria in location determination are explored then designed into decision support models using the Matlab fuzzy tool box. The results showed that there are three key criteria for determining the location of SPR development of cattle beef, namely 1) potential Feed from plants; 2) population of cattle beef; and the availability of facilities and infrastructure. Decision support model is built with fuzzy inference system technique using Triangular Fuzzy Number (TFN) representation model and MAMDANI inference method. The number of rules built as many as seven rules with the operator or and and and. Model simulation results show that the locations that are categorized as Very Suitable for SPR development of cattle beef are Silo, Sumberjambe, and Ledokombo Subdistricts, While sub District Gumukmas, Sumberbaru, Puger, Wuluhan, Kencong, Bangsalsari, Mumbulsari, and Jenggawah, fall into the Suitable category.
\end{abstract}

Keywords: fuzzy inference system, community farming center (SPR), cattle beef, location determining

\section{PENDAHULUAN}

Pemerintah Republik Indonesia terus mengupayakan terwujudnya swasembada daging sapi guna memenuhi kebutuhan daging dalam negeri yang semakin meningkat. Hingga kini, kekurangan pasokan daging sapi nasional masih dipenuhi dari impor baik dalam bentuk daging beku atau ternak hidup (Harmini dkk., 2011). Menurut Kementerian Pertanian RI (2016) rata-rata produksi daging sapi nasional adalah 504.51 ribu ton atau setara dengan sekitar 15.5 juta ekor sapi. Produksi daging sapi pada tahun 2015 mencapai 506.66 ribu ton atau meningkat $1.81 \%$ dibandingkan tahun
2014 sebesar 497.67 ribu ton. Walaupun demikian, pada tahun 2015 Indonesia masih mengalami defisit daging sapi sebesar 237.89 ribu ton atau setara dengan 1.39 juta ternak hidup.

Pemerintah melalui Kementerian Pertanian sebelumnya telah mencanangkan Program Swasembada Daging Sapi (PSDS) sejak tahun 2005 yang pelaksanaannya telah dilakukan secara bertahap dengan tujuan untuk mengurangi ketergantungan pasokan daging impor serta menciptakan kemandirian penyediaan daging sapi nasional. Program tersebut memprioritaskan pada upaya peningkatan produktivitas dan 
reproduktivitas sapi melalui Inseminasi Buatan (IB), peningkatan populasi ternak melalui penyediaan bibit dan pemeliharaan ternak, pengembangan kelembagaan melalui pembentukan kawasan peternaka, serta pengendalian perdagangan/impor sapi. Program tersebut melibatkan peternak skala kecil hingga swasta. Namun dalam prakteknya, keberhasilan program-program tersebut tidak terlalu menggembirakan (Ariningsih, 2014).

Tantangan terbesar dalam meningkatkan populasi sapi potong di Indonesia yaitu bagaimana meningkatkan pengelolaan sapi potong yang efisien pada peternakan rakyat yang mendominasi hingga $99 \%$ usaha peternakan di Indonesia. Peternakan rakyat merupakan peternak skala kecil dengan jumlah mencapai 5.6 juta orang dengan tingkat kepemilikan hanya $2-3$ ekor sapi/orang. Sebagian besar usaha ini bersifat sampingan saja sehingga peternak tidak mempunyai prioritas untuk mengalokasikan waktu, dana, dan tenaganya untuk upaya peningkatan skala usaha, disamping karena terbatasnya tempat dan kemampuan mengelola ternak. Masalah lain yang dihadapi adalah pengelolaan terhadap keterbatasan pakan, bibit, tingginya pemotongan sapi betina, sumberdaya peternak, dan tata niaga sapi. Hal inilah yang menyebabkan PSPD kurang berhasil mencapai target (Ilham dkk., 2011; Junaidi, 2013).

Dengan mempertimbangkan keadaan tersebut, maka sejak tahun 2014 Kementerian Pertanian melalui Direktorat Jenderal Peternakan dan Kesehatan Hewan (Ditjen PKH) tahun 2015, mengembangkan program khusus pengelolaan peternakan rakyat sapi potong melalui pembentukan Sentra Peternakan Rakyat (SPR). Melalui SPR, peternakan rakyat dikelola secara kolektif untuk meningkatkan kemudahan pelayanan teknis dan ekonomis yang pada akhirnya dapat meningkatkan daya saing usaha peternakan rakyat.

Kabupaten Jember merupakan salah satu produsen sapi potong di Provinsi Jawa Timur. Pada tahun 2015, populasi ternak sapi di wilayah ini mencapai 243.39 ribu ekor atau $5.7 \%$ dari populasi sapi potong Jawa Timur yang berjumlah 4.27 juta ekor (BPS, 2016). Menurut Dinas Peternakan, Perikanan, dan Kelautan Kabupaten Jember bahwa dalam rangka meningkatkan populasi sapi potong dan kesejahteraan peternak, maka mulai tahun 2016 pemerintah daerah akan mengembangkan SPR sapi potong di beberapa wilayah sentra. Kebijakan ini memerlukan memerlukan dukungan berupa informasi wilayah-wilayah kecamatan mana saja yang sesuai untuk pengembangan SPR agar nantinya program yang dijalankan dapat berhasil dengan baik.

Hingga saat ini, pemerintah Kabupaten Jember mempunyai permasalahan dalam menentukan wilayah kecamatan mana yang sesuai untuk digunakan sebagai lokasi pengembangan SPR sapi potong. Penelitian untuk mengidentifikasi kriteria-kriteria kunci dalam pemilihan lokasi pengembangan sangat mendesak untuk dilakukan. Selain itu, pengambil keputusan juga memerlukan sistem yang dapat digunakan untuk membantu pemilihan lokasi pengembangan untuk menjamin ketepatan hasil pemilihan sehingga SPR yang nantinya dibentuk dapat berhasil dikembangkan dengan secara efektif.

Penelitian ini bertujuan untuk menentukan lokasi pengembangan SPR sapi potong di Kabupaten Jember menggunakan teknik fuzzy inference system. Penelitian ini diharapkan dapat menghasilkan model pendukung keputusan pemilihan lokasi pengembangan SPR sapi potong. Hasil simulasi model akan diperoleh wilayah kecamatan 
mana saja yang sesuai bagi pengembangan SPR sapi potong.

Sistem Pakar fuzzy atau lebih dikenal sebagai fuzzy inference system merupakan penerapan sistem fuzzy dalam sistem pakar untuk mereprensentasikan pengetahuan pada lingkungan yang tidak pasti dan tidak lengkap serta sangat kompleks. Sistem tersebut merupakan pengembangan sistem pakar yang menggunakan logika fuzzy secara keseluruhan, yang meliputi gugus fuzzy, aturan IF - THEN, serta proses inferensi (Marimin, 2005).

Logika fuzzy yang umum digunakan dalam penarikan kesimpulan adalah Metode Mamdani dan Sugeno. Metode yang pertama diperkenalkan oleh Ebrahim Mamdani pada tahun 1975, sedangkan yang kedua dipopulerkan oleh Takagi, Sugeno dan Kang pada tahun 1985. Pada metode Mamdani, baik input (anteseden) maupun output (konsekuen) sistem berupa himpunan fuzzy, sedangkan pada metode Sugeno outputnya bukan berupa himpunan fuzzy melainkan berupa konstanta atau persamaan linear (Kusumadewi, 2002).

Proses inferensi pada Sistem Pakar fuzzy adalah sebagai berikut:

a. Melakukan fuzzyfication, yaitu dengan menentukan variabel linguistik dan model fungsi keanggotaan (membership function) dari variabel tersebut.

b. Menentukan operator fuzzy, yaitu apabila anteseden lebih dari satu maka perlu ditetapkan operasi hubungan fuzzy antar anteseden - anteseden tersebut.

c. Menentukankan aturan (rules) if..then Aturan if-then dalam sistem inferensi fuzzy dengan menggunakan metode MAMDANI mempunyai bentuk sebagai berikut:

IF $\mathrm{x}$ adalah rendah dan y adalah tinggi THEN $\mathrm{z}=$ sedang dimana variabel input (anteseden) maupun output (konsekuen sistem berupa himpunan fuzzy.

Pada metode Sugeno, aturan if-then berbentuk, sebagai berikut:

IF $\mathrm{x}=\mathrm{A}$ dan $\mathrm{y}=\mathrm{B}$, maka $\mathrm{z}=$ $\mathrm{F}[\mathrm{x}, \mathrm{y}]$

dimana A dan B merupakan gugus fuzzy dalam anteseden dan $\mathrm{z}=\mathrm{F}[\mathrm{x}, \mathrm{y}]$ adalah konstanta atau persamaan linear.

d. Melakukan inference, yaitu melakukan penghitungan nilai kebenaran untuk setiap premis dari setiap aturan yang menghasilkan output gugus fuzzy.

e. Agregation, yaitu menggabungkan seluruh output gugus fuzzy menjadi sebuah output gugus fuzzy

f. Defuzzyfication, yaitu proses pengubahan hasil fuzzy menjadi hasil yang mempunyai nilai tunggal (crisp).

\section{METODE PENELITIAN}

Tahapan penelitian terdiri dari dua tahapan utama, yaitu tahap pertama adalah perancangan model penunjang keputusan pemilihan lokasi pengembangan SPR sapi potong; sedangkan tahap kedua adalah melakukan simulasi model yang dihasilkan untuk menentukan lokasi pengembangan sebagaimana ditunjukkan pada Gambar 1. Adapun tahapan kegiatan adalah sebagai berikut:

1. Perancangan model penunjang keputusan pemilihan lokasi pengembangan SPR sapi potong. Tahapan yang dilakukan adalah sebagai berikut:

a. Studi pendahuluan; Tahapan ini bertujuan untuk mengidentifikasi dan menetapkan kriteria kunci pengembangan SPR sapi potong guna menyusun instrumen survei. Studi ini mencakup kajian pustaka, observasi dan wawancara dengan narasumber ahli. Berdasarkan studi pendahuluan selanjutnya dirancang instrumen penelitian, baik berupa 
kuesioner, panduan wawancara dan panduan observasi.

b. Penetapan responden penelitian; Tahapan ini bertujuan untuk menetapkan responden yang akan diwawancarai untuk mengisi instrumen penelitian yan telah dihasilkan.

c. Pengumpulan data; Tahapan ini bertujuan mengumpulkan data melalui survey lapang berdasarkan instrumen penelitian pada sampel penelitian yang telah ditetapkan.

d. Pengolahan dan analisis data; Data hasil survei diolah secara deskriptif untuk mendapatkan gambaran potensi wilayah kecamatan terkait dengan pengembangan SPR sapi potong. Selanjutnya dilakukan analisis untuk mendapat faktor kunci pemilihan lokasi dengan teknik deskriptif. Hasil yang diperoleh kemudian digunakan untuk merancang model pemilihan lokasi dengan teknik fuzzy inference sistem. Secara teknis, langkahlangkah yang dilakukan pada perancangan model adalah sebagai berikut 1) fuzzifikasi variabel input maupun output; 2) menentukan operator fuzzy; 3) menentukan aturan (rules) if..then dengan metode MAMDANI; 4) melakukan inferensi untuk setiap rule yang menghasilkan output gugus fuzzy; 5) melakukan agregasi dengan menggabungkan seluruh output gugus fuzzy menjadi sebuah output gugus fuzzy; dan 6) melakukan defuzzifikasi yaitu mengubah hasil fuzzy menjadi hasil yang mempunyai nilai tunggal (crisp).

Simulasi model penunjang keputusan pemilihan lokasi pengembangan SPR sapi potong. Pada tahapan ini model yang telah dihasilkan divalidasi dengan teknik Face validaty. Jika telah valid model kemudian digunakan untuk simulasi sehingga diperoleh wilayah kecamatan yang mempunyai prioritas tinggi dipilih sebagai lokasi pengembangan SPR sapi potong.

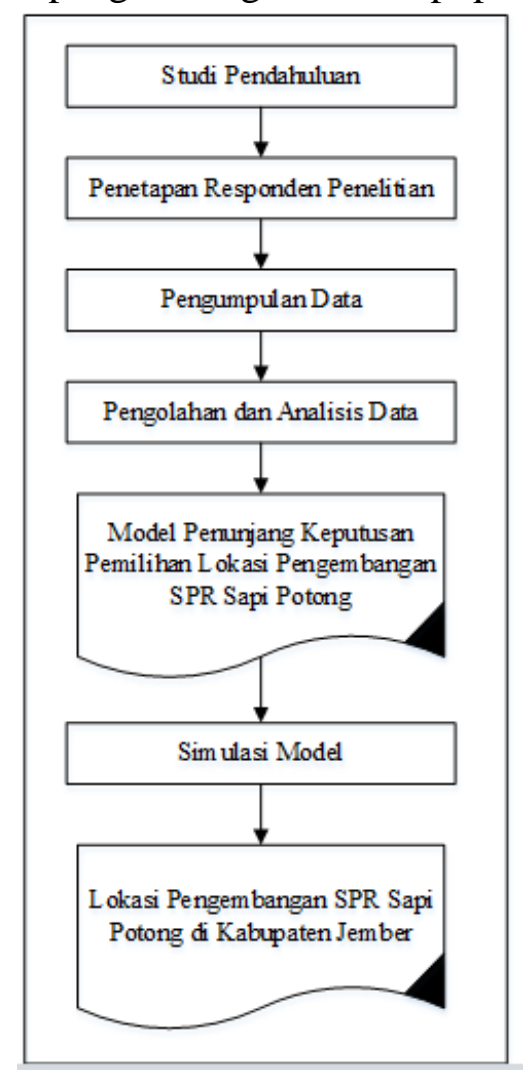

Gambar 1. Tahapan Penelitian

HASIL DAN PEMBAHASAN

\section{Faktor Kunci Pemilihan Lokasi Pengembangan SPR Sapi Potong}

Kebijakan peningkatan produksi dan produktivitas ternak di Kabupaten Jember dimaksudkan untuk mewujudkan Jember sebagai salah satu sentra ternak di Provinsi Jawa Timur pada lima tahun mendatang. Kondisi peternakan di Kabupaten Jember yang tidak ideal yang dicirikan dengan rendahnya tingkat kepemilikan ternak, skala usaha, produktivitas, aksesibilitas modal, dan kesejahteraan peternak menyebabkan pengembangannya harus melibatkan sinergi seluruh pihak untuk mengorganisasikan sumberdaya peternak berskala kecil menjadi suatu kelompok dalam kegiatan yang terintegrasi dan 
berkesinambungan mulai dari hulu, budidaya, hingga hilir.

Menurut Kementerian Pertanian melalui Direktorat Jenderal Peternakan dan Kesehatan Hewan (Ditjen PKH) tahun 2015, bahwa pendekatan yang sesuai untuk mengembangkan peternakan dengan kondisi sebagaimana disebutkan adalah melalui pengembangan Sentra Peternakan Rakyat (SPR). Pendekatan tersebut pada hakekatnya sesuai dengan Rencana Strategis Kementerian Pertanian 2010-2014 yang menyatakan bahwa peningkatan produksi dan nilai tambah komoditas unggulan pertanian, termasuk peternakan dilakukan melalui Pengembangan Kawasan Pertanian dimana kegiatan pertanian dilakukan secara utuh dan terpadu, serta fokus pada pencapaian sasaran yang ada khususnya sasaran pada komoditas utama.

Kriteria lokasi pengembangan SPR sapi potong ditentukan dengan menggunakan pendekatan Location Driven, yaitu dengan didasarkan atas potensi peternakan sapi potong rakyat yang saat ini telah ada, berkembang, dan menjadi usaha bagi sebagian besar peternak di wilayah yang dimaksud. Penetapan lokasi juga mempertimbangkan potensi pakan hijauan agar diperoleh produksi dan produktivitas ternak yang optimal dan berwawasan lingkungan, serta sarana dan prasarana yang dibutuhkan bagi terbentuknya SPR.

Sementara itu, dari aspek agroklimat Kabupaten Jember relatif sesuai untuk budidaya sapi potong karena sebagian besar wilayahnya berada pada dataran rendah hingga sedang mulai 0 hingga 500 meter dpl (76.4\%), ketinggian 500 sampai dengan $1.000 \mathrm{~m} \mathrm{dpl}(15,80 \%)$, dan ketinggian lebih dari $1.000 \mathrm{~m} \mathrm{dpl}(7,80 \%)$. Dataran yang relatif tinggi terletak di wilayah Jember bagian utara dan timur di lereng Gunung Argopuro dan Gunung Raung. Dataran yang landai dengan tingkat kelerengan kurang dari $8^{0}$ menjadi wilayah dominan sebesar 57\%. Kabupaten Jember mempunyai iklim tropis dengan suhu berkisar antara $23^{\circ} \mathrm{C}-31^{\circ} \mathrm{C}$. Tingkat curah hujannya pun tergolong sedang berkisar antara $1,000-1,750 \mathrm{~mm}$ per tahun. Sebagaimana daerah tropis lainnya, kelembaban di sebagian besar wilayah tergolong cukup tinggi sekitar $80 \%$. Keberadaan banyak mata air, sungai, dan curah hujan yang cukup menyebabkan ketersediaan air relatif mencukupi bagi kegiatan pertanian tanaman pangan sehingga sangat potensial dalam mendukung ketersediaan pakan hijauan ternak. Dengan kondisi tersebut, aspek persyaratan agroklimat bukanlah merupakan kendala serius bagi pengembangan SPR sapi potong di Kabupaten Jember.

a) Kriteria populasi ternak sapi potong Peternakan rakyat sapi potong tersebar di seluruh wilayah Kabupaten Jember. SPR sapi potong berpotensi dikembangkan diseluruh wilayah kabupaten, kecuali Kecamatan Kaliwates yang populasinya tidak sesuai dengan yang dipersyaratkan karena jumlahnya kurang dari 1,000 ekor. Dari kriteria ini terdapat 10 wilayah kecamatan yang sangat potensial dan mempunyai prioritas tinggi untuk dikembangkan menjadi SPR sapi potong, diantaranya adalah Kecamatan Gumukmas, Silo, Sumberbaru, Tempurejo, Sumberjambe, Puger, Wuluhan, Kencong, Ledokombo, dan Rambipuji.

Kriteria populasi ternak mencakup pula kelayakan teknis sapi potong. Menurut Ditjen PKH Kementerian Pertanian (2015), kelayakan teknis SPR sapi potong mencakup jumlah populasi dan kepemilikan ternak indukan. Wilayah dinilai layak secara teknis apabila populasi jumlah indukan sapi potong minimal adalah 1,000 ekor, jumlah populasi jantan maksimal 100, dan kepemilika ternak indukan maksimal 5 ekor per peternak Kelayakan teknis 
pengembangan SPR sapi potong ditunjukkan pada Tabel 1 yang memberikan informasi kesesuaian kondisi peternakan sapi potong existing dengan persyaratan teknis. Suatu wilayah dinilai layak apabila semua persyaratannya tercukupi, sedangkan predikat kurang layak diberikan jika kondisinya sedikit dibawah persyaratan, tidak layak jika memang keadaannya jauh dari persyaratan.

Tabel 1. Kelayakan teknis SPR sapi potong pada setiap wilayah kecamatan

\begin{tabular}{|c|c|c|c|c|c|c|}
\hline & Kecamatan & $\begin{array}{l}\text { Populasi } \\
\text { (ekor) }\end{array}$ & $\begin{array}{l}\text { Indukan } \\
\text { (ekor)* }^{*}\end{array}$ & $\begin{array}{l}\text { Jantan } \\
\text { (ekor)* }^{*}\end{array}$ & $\begin{array}{c}\text { Kepemilikan } \\
\text { (ekor/peternak) }\end{array}$ & $\begin{array}{c}\text { Kelayakan } \\
\text { Teknis }\end{array}$ \\
\hline 1 & Gumukmas & 16,856 & 14,126 & 2,730 & 1.98 & Layak \\
\hline 2 & Silo & 16,410 & 13,752 & 2,658 & 2.00 & Layak \\
\hline 3 & Sumberbaru & 14,730 & 12,345 & 2,385 & 1.97 & Layak \\
\hline 4 & Tempurejo & 14,042 & 11,768 & 2,274 & 2.00 & Layak \\
\hline 5 & Sumberjambe & 13,916 & 11,662 & 2,254 & 1.99 & Layak \\
\hline 6 & Puger & 13,008 & 10,901 & 2,107 & 1.99 & Layak \\
\hline 7 & Wuluhan & 12,243 & 10,260 & 1,983 & 2.00 & Layak \\
\hline 8 & Kencong & 11,224 & 9,406 & 1,818 & 2.00 & Layak \\
\hline 9 & Ledokombo & 9,737 & 8,160 & 1,577 & 2.00 & Layak \\
\hline 10 & Rambipuji & 8,909 & 7,466 & 1,443 & 2.00 & Layak \\
\hline 11 & Bangsalsari & 8,330 & 6,981 & 1,349 & 2.00 & Layak \\
\hline 12 & Sukowono & 8,088 & 6,778 & 1,310 & 2.00 & Layak \\
\hline 13 & Jelbuk & 7,995 & 6,700 & 1,295 & 2.00 & Layak \\
\hline 14 & Mumbulsari & 7,955 & 6,667 & 1,288 & 2.00 & Layak \\
\hline 15 & Kalisat & 7,849 & 6,578 & 1,271 & 2.00 & Layak \\
\hline 16 & Ambulu & 7,741 & 6,487 & 1,254 & 1.96 & Layak \\
\hline 17 & Mayang & 7,217 & 6,048 & 1,169 & 2.00 & Layak \\
\hline 18 & Arjasa & 6,044 & 5,065 & 979 & 1.91 & Layak \\
\hline 19 & Jenggawah & 6,026 & 5,050 & 976 & 2.00 & Layak \\
\hline 20 & Balung & 5,682 & 4,762 & 920 & 1.97 & Layak \\
\hline 21 & Pakusari & 4,773 & 4,000 & 773 & 2.00 & Layak \\
\hline 22 & Panti & 4,521 & 3,789 & 732 & 1.98 & Layak \\
\hline 23 & Umbulsari & 4,430 & 3,713 & 717 & 1.98 & Layak \\
\hline 24 & Sukorambi & 4,327 & 3,626 & 701 & 1.98 & Layak \\
\hline 25 & Tanggul & 4,070 & 3,411 & 659 & 1.98 & Layak \\
\hline 26 & Ajung & 3,908 & 3,275 & 633 & 2.00 & Layak \\
\hline 27 & Patrang & 3,851 & 3,227 & 624 & 1.98 & Layak \\
\hline 28 & Jombang & 3,743 & 3,137 & 606 & 1.99 & Layak \\
\hline 29 & Sumbersari & 2,641 & 2,213 & 428 & 1.97 & Layak \\
\hline 30 & Semboro & 2,405 & 2,016 & 389 & 1.97 & Layak \\
\hline
\end{tabular}

b) Kriteria potensi pakan hijau ternak

Kriteria ini dimaksudkan untuk mengintegrasikan syarat teknis dengan dukungan ketersediaan pakan hijaun. Wilayah yang mempunyai daya dukung besar terhadap penyediaan pakan hijauan ternak dan memenuhi syarat teknis menjadi prioritas untuk dikembangkan menjadi SPR. Hingga saat ini, sebenarnya Kabupaten Jember merupakan salah satu wilayah sumber pakan terbesar di Indonesia. Lahan-lahan pertaniannya sangat produktif karena merupakan daerah subur dan cukup air. Adanya kendala 
keterbatasan pakan hijaun lebih disebabkan karena sebagaian besar peternak belum mampu untuk melalukan konversi hijauan menjadi bentuk yang lebih awet guna membuat stok pakan yang sesuai kebutuhan ternaknya. Dengan pendekatan ini, lokasi SPR nantinya akan berada di wilayah sumber pakan hijauan, atau mendekati wilayah sumber pakan, sehingga kontinuitas penyediaannya dapat terjamin.

Pada Tabel 2 ditunjukkan 10 wilayah kecamatan yang mempunyai potensi besar untuk menghasilkan pakan hijauan ternak. Sumber pakan hijaun dapat berasal dari dedaunan tanaman padi (jerami), jagung, legume (lamtoro, turi, kacang-kacangan, gamal, dsb), ubi kayu, ubi jalar, rumput-rumputan, tanaman kebun (pisang, kopi, kakao, pepaya, nangka, sengon), dan tanaman liar (paku- pakuan, mahoni, waru, sono, dsb). Kriteria yang digunakan adalah luas lahan yang tersedia untuk lahan pertanian sawah dan bukan sawah (tegal, perkebunan, hutan rakyat, padang penggembalaan, lahan yang belum dimanfaatkan, dan hutan negara). Lahan yang belum dimanfaatkan sangat potensial untuk digunakan sebagai lahan budidaya rumput gajah atau jenis rumput-rumputan unggul lainnya.

Hasil identifikasi menunjukkan beberapa wilayah kecamatan yang sesuai untuk pengembangan SPR ternak sapi potong. Wilayah Kecamatan Bangsalsari berada pada prioritas pertama dengan total luas lahan pertaniannya sebesar 19.73 ribu hektar, terdiri dari 4.48 ribu lahan sawah dan 15.24 ribu lahan bukan sawah. Berikutnya adalah Kecamatan Ledokombo, Sumberjambe, Silo, Tanggul, Panti dan yang terakhir Gumukmas.

Tabel 2. Potensi lahan pertanian sumber pakan hijauan ternak

\begin{tabular}{clccc}
\hline & Kecamatan & \multicolumn{3}{c}{ Potensi lahan pertanian } \\
\cline { 3 - 5 } & Bangsalsari & $\begin{array}{c}\text { Lahan pertanian } \\
\text { sawah (ha) }\end{array}$ & $\begin{array}{c}\text { Lahan pertanian } \\
\text { bukan sawah (ha) }\end{array}$ & $\begin{array}{c}\text { Total luas lahan } \\
\text { (ha) }\end{array}$ \\
\hline 1 & Ledokombo & 4,486 & 15,240 & 19,726 \\
2 & Sumberjambe & 3,090 & 10,157 & 13,247 \\
3 & S i lo & 1,958 & 10,504 & 12,462 \\
4 & Tanggul & 1,546 & 10,372 & 11,918 \\
5 & P a n t i & 3,750 & 6,525 & 10,275 \\
6 & Mumbulsari & 2,410 & 6,268 & 8,678 \\
7 & Sumberbaru & 2,292 & 5,926 & 8,218 \\
8 & Wuluhan & 3,981 & 3,786 & 7,767 \\
9 & Gumukmas & 4,194 & 3,053 & 7,247 \\
10 & Total & 4,200 & 2,966 & 7,166 \\
\hline
\end{tabular}

c) Kriteria sarana dan prasarana wilayah Menurut Direktorat Jenderal Peternakan dan Kesehatan Hewan (Ditjen PKH) tahun 2015 bahwa pembentukan SPR sapi potong memerlukan persyaratan sarana dan prasarana untuk mendukung pelayanan kepada peternak, baik layanan teknis, layanan pemasaran, layanan ekonomi, pendampingan dan pengawalan SDM,serta dukungan swasta. Berikut ini adalah sarana dan prasarana yang diperlukan sebagai syarat pembentukan SPR, yaitu:

1) Sarana dan layanan teknis; puskewan, pos IB (iseminasi buatan), laboratorium kesehatan hewan, recording, dan pakan

2) Sarana dan layanan pemasaran; RPH, pemasaran, serta promosi dan investasi

3) Pendampingan dan pengawalan SDM, penyuluh, perguruan tinggi, 
balai/badan penelitian, sekolah peternakan rakyat, dan lembagalembaga terkait

4) Layanan ekonomi; skim pembiayaan, industri pakan, toko obat/vaksin, dan LKMM.

5) Dukungan swasta; asuransi, kemitraan, dan asuransi.

Perancangan Model Pendukung Keputusan Pemilihan Lokasi Pengembangan SPR Sapi Potong

Kriteria yang diperoleh kemudian digunakan sebagai dasar dalam menentukan lokasi pengembangan SPR sapi potong. Dalam pemilihan lokasi, digunakan metode fuzzy inference system dengan tahapan-tahapan sebagai berikut:

1. Melakukan fuzzifikasi kriteria

Kriteria pemilihan ditetapkan sebagai variabel input, sedangkan variabel outputnya adalah kesesuaian lokasi. Kedua variabel tersebut selanjutnya dilakukan fuzzifikasi dengan cara memberikan variabel linguistik yang mencerminkan intensitas dari kriteria. Hasil fuzzifikasi adalah himpunan fuzzy (fuzzy set). Himpunan fuzzy untuk variabel input dan output, adalah sebagai berikut:

\section{Variabel input :}

Hijauan $=$ Kurang Melimpah pakan $\quad(\mathrm{K})$; Cukup Melimpah

(HP)
(C); Sangat Melimpah
(S)

Populasi $=$ Rendah $(\mathrm{R}) ;$ Sedang ternak (S); Tinggi (T)

(PT)

Sarana \& $=$ Kurang Memadai prasarana $\quad(\mathrm{KM})$; Memadai $(\mathrm{M})$; (SS) Sangat Memadai (SM)

\section{Variabel}

\section{output :}

Kesesuaian $=$ Kurang Sesuai (KS); Lokasi (L) Sesuai (S); Sangat Sesuai (SS)

2. Menentukan model fungsi keanggotaan fuzzy (membership function). Model fungsi keanggotaan fuzzy yang digunakan adalah tringular fuzzy number (TFN) dan Trapezoidal. Bilangan fuzzy yang digunakan untuk merepresentasikan variabel dalam model adalah 0 sampai 100 yang dinyatakan sebagai berikut:

$$
\mathrm{BB}=[\mathrm{p} \mid 0 \leq \mathrm{p} \leq 100] ; \quad \mathrm{P}=[\mathrm{q} \mid 0
$$

$\leq \mathrm{q} \leq 100] ; \mathrm{NT}=[\mathrm{r} \mid 0 \leq \mathrm{r} \leq 100]$;

$$
\mathrm{A}=[\mathrm{z} \mid 0 \leq \mathrm{z} \leq 100]
$$

Representasi variabel hijauan pakan, populasi ternak, dan sarana dan prasarana mempunyai bentuk yang sama dan ditunjukkan oleh Gambar 2, sedangkan representasi untuk variabel lokasi pada Gambar 3.

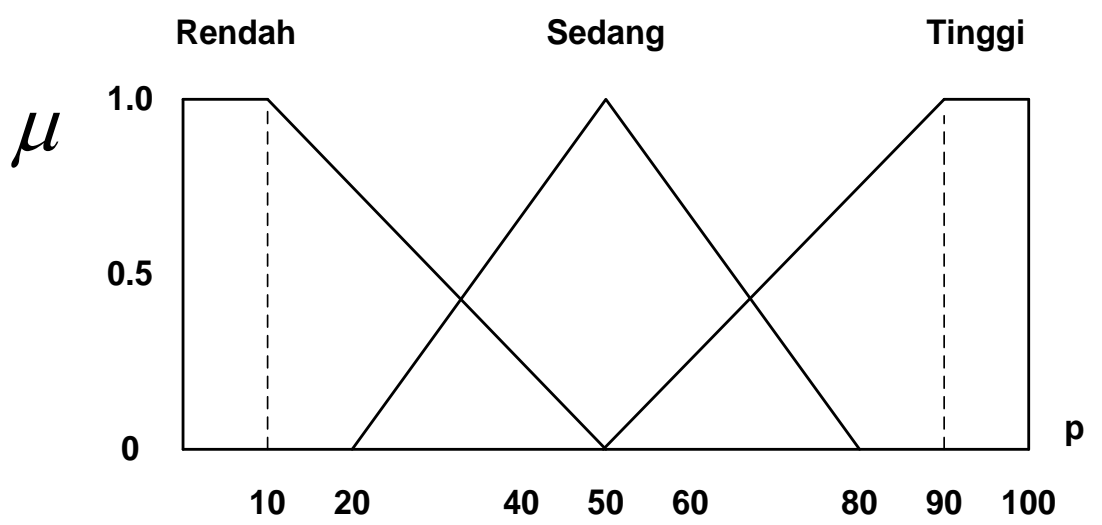

Gambar 2. Representasi variabel: hijauan pakan, populasi ternak, dan sarana dan prasarana mempunyai bentuk model yang sama 


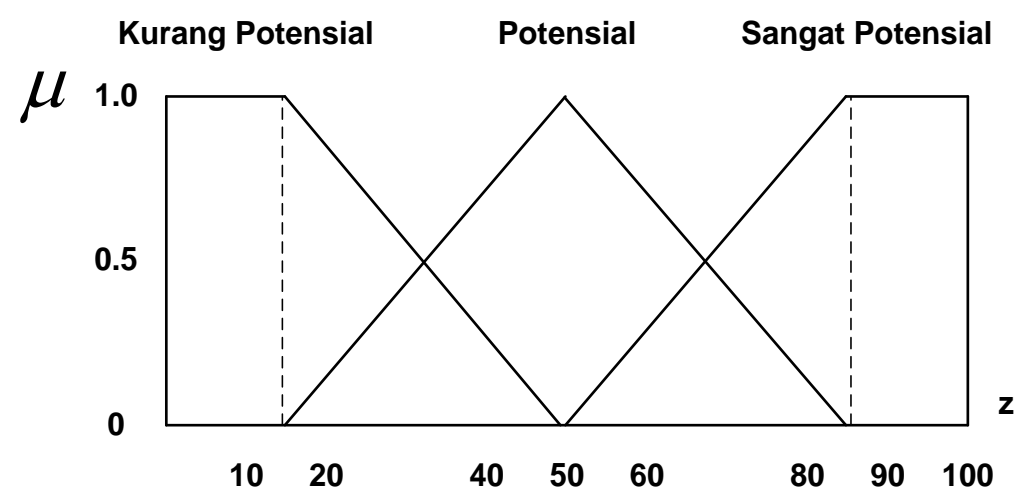

Gambar 3. Representasi variabel lokasi pengembangan SPR

Fungsi keanggotaan untuk variabel hijauan pakan, populasi ternak, dan sarana dan prasarana adalah sebagai berikut:

Fungsi keanggotaan untuk variabel linguistik rendah adalah sebagai berikut;

$$
\mu_{\text {BBR }[\mathrm{p}]}=\mid \begin{array}{ll}
1 ; & \mathrm{p} \leq 10 \\
\frac{50-\mathrm{p}}{40} ; & 10 \leq p \leq 50 \\
0 ; & \mathrm{p} \geq 50
\end{array}
$$

Fungsi keanggotaan $(\mu)$ untuk variabel linguistik sedang adalah sebagai berikut;

$$
\mu \text { BBS[p] } \mid \begin{aligned}
& 0 ; \mathrm{z} \leq 10 \text { atau } \mathrm{z} \geq 90 \\
& \frac{\mathrm{p}-10}{40} ; 10 \leq p \leq 50 \\
& \frac{90-p}{40} ; 50 \leq p \leq 90
\end{aligned}
$$

Fungsi keanggotaan ( $\left.{ }^{\mu}\right)$ untuk variabel linguistik tinggi adalah sebagai berikut;

$$
\mu \text { BBT[p] } \mid \begin{gathered}
0 ; \mathrm{p} \leq 50 \\
\frac{\mathrm{p}-50}{40} ; 50 \leq p \leq 90 \\
1 ; p \geq 90
\end{gathered}
$$

Fungsi keanggotaan untuk variabel kesesuaian lokasi adalah sebagai berikut;

Fungsi keanggotaan $(\mu)$ untuk variabel linguistik kurang sesuai adalah;

$$
\mu \mathrm{A} K P[\mathrm{z}] \mid \begin{gathered}
1 ; \mathrm{z}<10 \\
\frac{50-\mathrm{z}}{40} ; 10 \leq z \leq 50 \\
0 ; z>50
\end{gathered}
$$

Fungsi keanggotaan $(\mu)$ untuk variabel linguistik sesuai adalah sebagai berikut;

$$
\mu \mathrm{A} P o t[\mathrm{z}] \mid \begin{aligned}
& 0 ; \mathrm{z} \leq 10 \text { atau } \mathrm{z} \geq 90 \\
& \frac{\mathrm{z}-10}{40} ; 10 \leq z \leq 50 \\
& \frac{90-z}{40} ; 50 \leq z \leq 90
\end{aligned}
$$

Fungsi keanggotaan $(\mu)$ untuk variabel linguistik sangat sesuai adalah;

$$
\mu \mathrm{A} S P[\mathrm{z}] \mid \begin{gathered}
0 ; \mathrm{z} \leq 50 \\
\frac{\mathrm{z}-50}{35} ; 50 \leq z \leq 90 \\
1 ; z \geq 90
\end{gathered}
$$

3. Pembentukan aturan (if ...then rules) Pemilihan lokasi pengembangan SPR sapi potong mengikuti aturanaturan pokok yang dikembangkan berdasarkan kriteria yang telah ditetapkan sebelumnya. Berdasarkan pertimbangan pakar, maka diperoleh tujuh aturan pemilihan sebagaimana 
disebutkan dibawah ini. Oleh karena input maupun outputnya berupa variabel linguistik, maka metode inferensi yang digunakan adalah metode MAMDANI :

Aturan 1 : IF hijauan pakan (HP) kurang melimpah (K) OR populasi ternak (PT) rendah

(R) OR sarana \& prasarana (SS) kurang Memadai (KM) THEN lokasi (L)

Tidak Sesuai (TS)

Aturan $2 \quad: \quad \mathrm{IF} \quad \mathrm{HP}=\mathrm{S} \quad$ AND $\quad \mathrm{PT}=\mathrm{T} \quad$ AND $\quad \mathrm{SS}=\mathrm{M} \quad$ THEN $\mathrm{L}=\mathrm{SS}$

Aturan $3:$ IF $\mathrm{HP}=\mathrm{C} \quad$ AND $\quad \mathrm{PT}=\mathrm{S} \quad$ AND $\mathrm{SS}=\mathrm{CM} \quad \mathrm{THEN} \quad \mathrm{L}=\mathrm{S}$

Aturan $4:$ IF $\mathrm{HP}=\mathrm{S} \quad$ AND $\mathrm{PT}=\mathrm{S} \quad$ AND $\mathrm{SS}=\mathrm{M} \quad$ THEN $\mathrm{L}=\mathrm{S}$

Aturan 5 : IF $\mathrm{HP}=\mathrm{C} \quad$ AND $\quad \mathrm{PT}=\mathrm{T} \quad \mathrm{AND} \quad \mathrm{SS}=\mathrm{M} \quad$ THEN $\mathrm{L}=\mathrm{SS}$

Aturan $6:$ IF $\mathrm{HP}=\mathrm{S} \quad \mathrm{AND} \quad \mathrm{PT}=\mathrm{S} \quad \mathrm{AND} \quad \mathrm{SS}=\mathrm{CM} \quad \mathrm{THEN} \quad \mathrm{L}=\mathrm{S}$

Aturan $7 \quad$ : $\quad \mathrm{IF} \quad \mathrm{HP}=\mathrm{C}$ AND $\quad \mathrm{PT}=\mathrm{T} \quad$ AND $\quad \mathrm{SS}=\mathrm{CM} \quad \mathrm{THEN} \quad \mathrm{L}=\mathrm{S}$

4. Evaluasi aturan

Dengan menggunakan operator fuzzy

OR atau AND, maka diperoleh hasil aplikasi sebagai berikut:

Apabila diberikan input hijauan pakan (HP) sebesar $\mathrm{p}_{0}$, kemudian input populasi ternak (PT) sebesar $\mathrm{x}_{0}$, dan input sarana dan prasarana (SS) sebesar $\mathrm{r}_{0}$, maka hasil aplikasi operator fuzzy (output) untuk setiap aturan dapat dinyatakan $\alpha$. Nilai $\alpha$ merupakan nilai fungsi keanggotaan ( $\mu$ ) yang bernilai antara 0 dan 1 atau

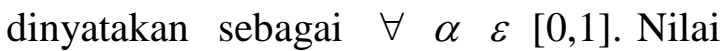
$\alpha$ untuk setiap aturan dinyatakan dengan persamaan sebagai berikut:

$$
\begin{array}{llll}
\text { Aturan } & 1 & : & \operatorname{Max} \quad\left[\mu_{B B R}\left(p_{0}\right),\right. \\
\left(\alpha_{1}\right) & & & \left.\mu_{P R}\left(p_{0}\right), \mu_{N T R}\left(p_{0}\right)\right] \\
& & : & \operatorname{Min}\left[\mu_{B B R}\left(p_{0}\right), \mu_{P R}\left(p_{0}\right)\right. \\
\text { Aturan } & 2 & & \\
\left(\alpha_{2}\right) & & & \\
& & \left.\mu_{N T R}\left(p_{0}\right)\right]
\end{array}
$$

Oleh karena aturan ketiga sampai ketujuh menggunakan operator fuzzy yang sama, maka $\alpha_{3}, \alpha_{4}$ sampai $\alpha_{7}$ mempunyai persamaan yang sama dengan $\alpha_{2}$.

Selanjutnya, implikasi masingmasing aturan dianalisis dengan membandingkan nilai-nilai $\alpha$ yang telah diperoleh dengan model representasi fungsi keanggotaan output. Analisis ini menghasilkan daerah solusi output untuk masing-masing aturan. Daerah solusi atau sering disebut solusi himpunan fuzzy adalah daerah yang berada pada interval nilai $\mathrm{z}$ tertentu.

\section{Agregasi Output}

Agregasi output dilakukan dengan melakukan komposisi daerah solusi output yang dihasilkan oleh masing-masing aturan. Agregasi akan menghasilkan daerah solusi yang merefleksikan kontribusi dari setiap aturan. Agregasi dilakukan dengan metode MAX dan dapat dinyatakan sebagai berikut:

$$
\mu_{s f}\left[x_{i}\right] \rightarrow \operatorname{Max}\left(\mu_{\mathrm{sf}}\left[x_{i}\right], \mu_{k f}\left[x_{i}\right]\right)
$$

dimana :

$\mu_{s f}\left[x_{i}\right]=$ nilai keanggotaan solusi fuzzy sampai aturan ke-i

$\mu_{k f}\left[x_{i}\right]=$ nilai keanggotaan konsekuensi fuzzy (output) aturan ke-i

\section{Defuzzifikasi}

Output yang diperoleh dari proses agregasi adalah suatu himpunan fuzzy, yaitu nilai yang mempunyai range tertentu, belum mempunyai nilai crisp (tunggal). Agar diperoleh nilai tunggal maka dilakukan proses defuzzifikasi. Dalam kajian ini, defuzzifikasi dilakukan dengan metode Centroid. Pada metode Centroid, nilai crisp diperoleh dengan cara mengambil titik pusat daerah fuzzy. Untuk mencari nilai $\mathrm{z}$ dengan metode Centroid dinyatakan dengan persamaan:

$$
z=\frac{\sum_{j=1}^{n} z_{j} \mu\left(z_{j}\right)}{\sum_{j=1}^{n} \mu\left(z_{j}\right)}
$$

Program komputer yang digunakan untuk membantu analisis pemilihan lokasi pengembangan SPR sapi potong dengan metode fuzzy inference system adalah Tool Box Matlab 2009a. Model pendukung keputusan pemilihan lokasi 
pengembangan SPR sapi potong ditunjukkan pada Gambar 4, sedangkan komposisi aturan fuzzy, implikasi, agregasi dan defuzzifikasi dapat dilihat pada Gambar 5.
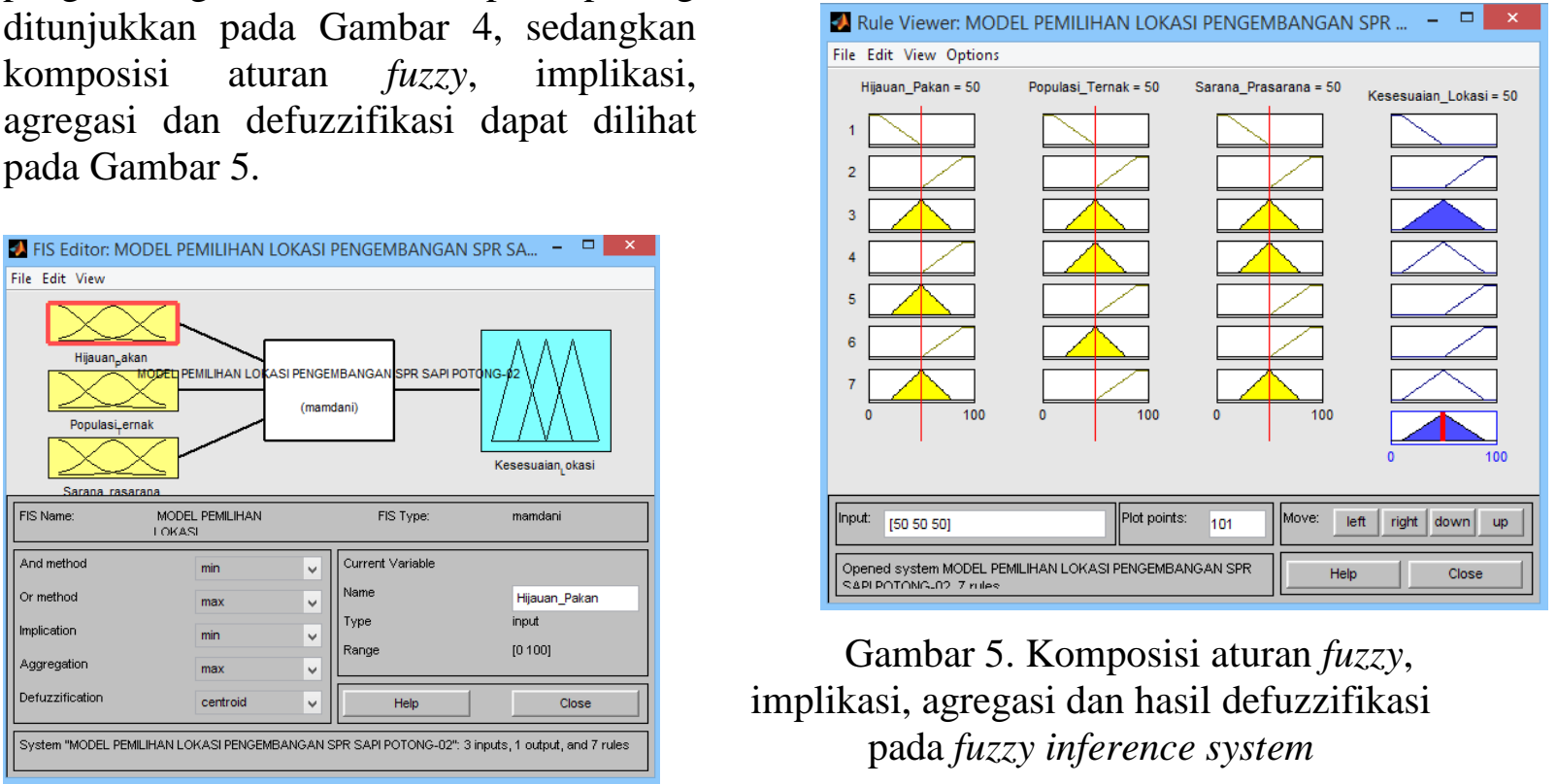

Gambar 5. Komposisi aturan fuzzy, implikasi, agregasi dan hasil defuzzifikasi pada fuzzy inference system

Gambar 4. Model pendukung keputusan pemilihan lokasi pengembangan SPR sapi potong dengan fuzzy inference system

Tabel 3. Nilai aktual dan skor penilaian dari kriteria pemilihan lokasi

\begin{tabular}{lcccc}
\hline Kecamatan & $\begin{array}{c}\text { Populasi } \\
\text { Ternak (Ekor) }\end{array}$ & $\begin{array}{c}\text { Potensi Luas } \\
\text { Lahan Hijaun } \\
\text { Pakan (Ha) }\end{array}$ & $\begin{array}{c}\text { Sarana } \\
\text { \& Prasarana }\end{array}$ \\
\hline 1 & Gumukmas & 16,856 & 7,166 & 79.90 \\
2 & Silo & 16,410 & 11,918 & 81.53 \\
3 & Sumberbaru & 14,730 & 7,767 & 71.63 \\
4 & Tempurejo & 14,042 & 3,970 & 76.63 \\
5 & Sumberjambe & 13,916 & 12,462 & 81.63 \\
6 & Puger & 13,008 & 5,485 & 74.89 \\
7 & Wuluhan & 12,243 & 7,247 & 75.00 \\
8 & Kencong & 11,224 & 5,343 & 78.30 \\
9 & Ledokombo & 9,737 & 13,247 & 78.30 \\
10 & Rambipuji & 8,909 & 4,456 & 39.79 \\
11 & Bangsalsari & 8,330 & 19,726 & 83.30 \\
12 & Sukowono & 8,088 & 3,624 & 64.87 \\
13 & Jelbuk & 7,995 & 3,418 & 66.49 \\
14 & Mumbulsari & 7,955 & 8,218 & 66.63 \\
15 & Kalisat & 7,849 & 4,636 & 38.26 \\
16 & Ambulu & 7,741 & 4,396 & 81.63 \\
17 & Mayang & 7,217 & 4,663 & 33.02 \\
18 & Arjasa & 6,044 & 3,323 & 36.59 \\
19 & Jenggawah & 6,026 & 5,283 & 30.00 \\
20 & Balung & 5,682 & 3,591 & 26.57
\end{tabular}




\begin{tabular}{lcrrr}
21 & Pakusari & 4,773 & 2,366 & 25.96 \\
22 & Panti & 4,521 & 8,678 & 21.54 \\
23 & Umbulsari & 4,430 & 6,286 & 66.63 \\
24 & Sukorambi & 4,327 & 2,926 & 21.54 \\
25 & Tanggul & 4,070 & 10,275 & 78.30 \\
26 & Ajung & 3,908 & 5,040 & 18.17 \\
27 & Patrang & 3,851 & 3,015 & 18.17 \\
28 & Jombang & 3,743 & 5,181 & 68.04 \\
29 & Sumbersari & 2,641 & 2,954 & 16.51 \\
30 & Semboro & 2,405 & 3,590 & 20.00 \\
\hline
\end{tabular}

\section{Simulasi Model}

Model yang diperoleh selanjutnya disimulasikan untuk memperoleh lokasi pengembangan SPR sapi potong yang sesuai di Kabupaten Jember. Data yang diinputkan adalah nilai dari kriteriakriteria pemilihan. Data kriteria populasi ternak dan potensi luas lahan hijauan pada tabel tersebut merupakan nilai aktual, sedangkan data sarana dan prasarana merupakan rata-rata nilai skor penilaian dari tiga orang pakar. Rentang penilaian menggunakan skor antara $1-100$.
Semakin tinggi nilainya, semakin baik ketersediaan sarana dan sarana yang ada.

Data kriteria populasi ternak dan potensi luas lahan hijauan pada Tabel 3 kemudian dikonversi menjadi nilai antara $1-100$ sesuai dengan representasi nilai dari variabel-variabel kriteria, sehingga diperoleh nilai input sebagaimana ditunjukkan pada Tabel 4. Nilai tertinggi populasi ternak dan hijauan pakan sesuai dengan hasil wawancara dengan pakar masing-masing adalah 20,000 ekor dan 20,000 ha.

Tabel 4. Nilai input kriteria yang dimasukkan ke dalam model

\begin{tabular}{clrrr}
\hline & Kecamatan & Populasi Ternak & \multicolumn{2}{c}{ Hijaun } \\
pakan & \multicolumn{2}{c}{ Sarana } \\
\& Prasarana \\
\hline 1 & Gumukmas & 84.28 & 35.83 & 79.90 \\
2 & Silo & 82.05 & 59.59 & 81.53 \\
3 & Sumberbaru & 73.65 & 38.835 & 71.63 \\
4 & Tempurejo & 70.21 & 19.85 & 76.63 \\
5 & Sumberjambe & 69.58 & 62.31 & 81.63 \\
6 & Puger & 65.04 & 27.425 & 74.89 \\
7 & Wuluhan & 61.22 & 36.235 & 75.00 \\
8 & Kencong & 56.12 & 26.715 & 78.30 \\
9 & Ledokombo & 48.69 & 66.235 & 78.30 \\
10 & Rambipuji & 44.55 & 22.28 & 39.79 \\
11 & Bangsalsari & 41.65 & 98.63 & 83.30 \\
12 & Sukowono & 40.44 & 18.12 & 64.87 \\
13 & Jelbuk & 39.98 & 17.09 & 66.49 \\
14 & Mumbulsari & 39.78 & 41.09 & 66.63 \\
15 & Kalisat & 39.25 & 23.18 & 38.26 \\
16 & Ambulu & 38.71 & 21.98 & 81.63
\end{tabular}




\begin{tabular}{llrrr}
17 & Mayang & 36.09 & 23.315 & 33.02 \\
18 & Arjasa & 30.22 & 16.615 & 36.59 \\
19 & Jenggawah & 30.13 & 26.415 & 30.00 \\
20 & Balung & 28.41 & 17.955 & 26.57 \\
21 & Pakusari & 23.87 & 11.83 & 25.96 \\
22 & Panti & 22.61 & 43.39 & 21.54 \\
23 & Umbulsari & 22.15 & 31.43 & 66.63 \\
24 & Sukorambi & 21.64 & 14.63 & 21.54 \\
25 & Tanggul & 20.35 & 51.375 & 78.30 \\
26 & Ajung & 19.54 & 25.2 & 18.17 \\
27 & Patrang & 19.26 & 15.075 & 18.17 \\
28 & Jombang & 18.72 & 25.905 & 68.04 \\
29 & Sumbersari & 13.21 & 14.77 & 16.51 \\
30 & Semboro & 12.03 & 17.95 & 20.00 \\
\hline
\end{tabular}

Hasil simulasi model diperoleh Sumberbaru, Puger, Wuluhan, Kencong, bahwa lokasi yang berkatagori Sangat Bangsalsari, Mumbulsari, dan Jenggawah, Sesuai untuk pengembangan SPR sapi masuk dalam kategori Sesuai. Hasil potong adalah Kecamatan Silo, simulasi secara lengkap ditunjukkan pada Sumberjambe, dan Ledokombo, Tabel 5. sedangkan Kecamatan Gumukmas,

Tabel 5. Hasil simulasi model pemilihan lokasi pengembangan SPR sapi potong

\begin{tabular}{|c|c|c|c|c|}
\hline & Kecamatan & $\begin{array}{l}\text { Nilai } \\
\text { Output }\end{array}$ & $\begin{array}{l}\text { Kesesuaian } \\
\text { Lokasi }\end{array}$ & $\begin{array}{l}\text { Derajat } \\
\text { Keanggotaan (mf) }\end{array}$ \\
\hline 1 & Gumukmas & 55.30 & $S$ & 0.86 \\
\hline 2 & Silo & 81.20 & SS & 0.78 \\
\hline 3 & Sumberbaru & 58.50 & S & 0.78 \\
\hline 4 & Tempurejo & 18.30 & KS & 0.79 \\
\hline 5 & Sumberjambe & 79.80 & SS & 0.74 \\
\hline 6 & Puger & 39.60 & S & 0.74 \\
\hline 7 & Wuluhan & 47.30 & $\mathrm{~S}$ & 0.93 \\
\hline 8 & Kencong & 33.50 & $S$ & 0.58 \\
\hline 9 & Ledokombo & 72.20 & SS & 0.55 \\
\hline 10 & Rambipuji & 24.00 & $\mathrm{KS}$ & 0.65 \\
\hline 11 & Bangsalsari & 65.60 & $S$ & 0.61 \\
\hline 12 & Sukowono & 18.00 & KS & 0.80 \\
\hline 13 & Jelbuk & 17.80 & KS & 0.81 \\
\hline 14 & Mumbulsari & 44.70 & S & 0.86 \\
\hline 15 & Kalisat & 26.00 & $\mathrm{KS}$ & 0.60 \\
\hline 16 & Ambulu & 18.60 & KS & 0.79 \\
\hline 17 & Mayang & 26.30 & KS & 0.59 \\
\hline 18 & Arjasa & 17.80 & $\mathrm{KS}$ & 0.81 \\
\hline
\end{tabular}




\begin{tabular}{lllll}
19 & Jenggawah & 32.10 & S & 0.55 \\
20 & Balung & 18.00 & KS & 0.80 \\
21 & Pakusari & 17.10 & KS & 0.82 \\
22 & Panti & 22.30 & KS & 0.69 \\
23 & Umbulsari & 23.70 & KS & 0.66 \\
24 & Sukorambi & 17.50 & KS & 0.81 \\
25 & Tanggul & 19.60 & KS & 0.76 \\
26 & Ajung & 18.00 & KS & 0.80 \\
27 & Patrang & 17.60 & KS & 0.81 \\
28 & Jombang & 18.10 & KS & 0.80 \\
29 & Sumbersari & 17.30 & KS & 0.82 \\
30 & Semboro & 17.20 & KS & 0.82 \\
\hline
\end{tabular}

\section{KESIMPULAN DAN SARAN}

\section{Kesimpulan}

a) Model penunjang keputusan penentuan lokasi pengembangan SPR sapi potong di Kabupaten Jember telah dapat menghasilkan lokasi pengembangan yang sesuai dengan maksud pengambil kebijakan

b) Model penentuan lokasi pengembangan SPR sapi potong di Kabupaten Jember didasarkan atas 3 (tiga) kriteria kunci, yaitu 1) potensi pakan hijauan; 2) populasi ternak sapi potong; dan ketersediaan sarana dan prasarana.

c) Model penunjang keputusan dibangun dengan teknik fuzzy inference system menggunakan model representasi Triangular Fuzzy Number (TFN) dan metode inferensi MAMDANI. Jumlah rules yang dibangun sebanyak 7 (tujuh) aturan dengan operator or dan and. Model dibangun dengan menggunakan tool box fuzzy pada program Matlab.

d) Hasil simulasi model menunjukkan bahwa lokasi yang berkatagori Sangat Sesuai untuk pengembangan SPR sapi potong adalah Kecamatan Silo, Sumberjambe, dan Ledokombo, sedangkan Kecamatan Gumukmas, Sumberbaru, Puger, Wuluhan, Kencong, Bangsalsari, Mumbulsari, dan Jenggawah, masuk dalam kategori Sesuai

\section{Saran}

Guna meningkatkan validitas model, perlu dilakukan eksplorasi faktor-faktor kunci penentuan lokasi pengembangan SPR sapi potong, terutama yang berkaitan dengan aspek sumberdaya manusia peternak, keamanan wilayah, dan kondisi rantai pasok sapi potong.

\section{DAFTAR PUSTAKA}

Ariningsih E. 2014. Kinerja Kebijakan Swasembada Daging Sapi Nasional. Forum Penelitian Agro Ekonomi. Vol: 32. No. 2. Desember 2014: 137 - 156.

Badan Pusat Statistik. 2016. https://www.bps.go.id/linkTableD inamis/view/id/1016 [Diakses 15 April 2017]

Direktorat Jenderal Peternakan dan Kesehatan Hewan. 2015. Pedoman Sentra Peternakan Rakyat. Jakarta: Kementerian Pertanian RI.

Harmini, Asmarantaka RW, dan Atmakusuma J. 2011. Model Dinamis Sistem Ketersediaan Daging Sapi Nasional. Jurnal Ekonomi Pembangunan. Vol: 12. No. 1. Juni 2011: 128-146. 
Ilham NE, Basuno WK, Sejati, Ashari S, Nuryanti FBM, Dabukke, dan Elizabeth. 2011. Keragaan, Permasalahan dan Upaya Mendukung Akselerasi Program Swasembada daging Sapi. Laporan Hasil Penelitian. Bogor: Pusat Sosial Ekonomi dan Kebijakan Pertanian IPB.

Junaidi A. 2013. Menggagas Terwujudnya Swasembada Daging Sapi di Indonesia. [Paper]. Disampaikan pada Pidato Ilmiah Dies Natalis ke-67 Fakultas Kedokteran Hewan Universitas
Gajah Mada. 20 September 2013. Yogyakarta: UGM.

Kementerian Pertanian Republik Indonesia. 2016. Produksi Saping Sapi Propinsi. http://www.pertanian.go.id/NAK2016fix/Prod_DagingSapi_Prop 2016.pdf [Diakses 15 April 2017].

Kusumadewi K. 2002. Analisis dan desain Sistem Fuzzy Menggunakan Tool Box Matlab. Jakarta: Graha Ilmu.

Marimin. 2005. Teori dan Aplikasi Sistem Pakar dalam Teknologi Manajerial. Bogor: IPB Press 